\title{
CONCEPTS OF STROKE BEFORE AND AFTER VIRCHOW
}

\author{
by
}

\section{FRANCIS SCHILLER}

CONTRARY to chronology, or the logic of first things first-but to nobody's surprisethe latest ideas about strokes are readily accessible, while much effort is needed to bridge the gap lying in the direction of their past. ${ }^{1}$ Yet the essential observations go far back and are much hidden by contemporary, often ephemeral growth. We hardly get to see the wood for the leaves. Where are the stems that keep our knowledge green?

'Stroke' for us-unlike coup in French or Schlag in German-acquires its morbid meaning simply from the context. 'He had a stroke' needs no elaboration. Former ages, taking no semantic chances, would not let the word go unattended by a qualification such as 'paralytic' or 'apoplectic', used indiscriminately. In the Oxford English Dictionary the first synonym for the 'stroke of the palsy' is given as 'stroke of God's hands', 1599. Today, apoplexy sounds a little quaint. It is the classical striking off or down. The Latin equivalents morbus attonitus and sideratio-literally 'being thunderstruck'-suggest both a celestial force and an affliction of the mind.2 Embolism and thrombosis are usually traced, with good reason, to Virchow and the mid-nineteenth century. Thrombus, since antiquity, has been a coagulum, clot, or curd in blood and milk. In surgery it has done duty for the seal that is on a vessel punctured or severed. Embolus, long before Virchow, was in use for a variety of connotations different from his and ours. The odd, extra day that calendar-makers had to intercalate was an embolus. In surgeons' terminology it stood for throwing in of the humeral or femoral head to reduce a dislocation. In the seventeenth century the plunger of a syringe was an embole. ${ }^{3}$

We do not say 'apoplegia' or 'paraplexy', although we might. In the Greek and English language, chance or euphony have fixed these near homonyms and synonyms to be the way they are. Paraplegia or paraplexia, for Aretaeus, was but a minor variant, a 'para' or 'near' apoplexy. It is the incomplete or circumscribed loss of function, the páresis 'of a part only', 'the letting go of touch and motion in either a hand or a leg'. Paralysis was the more technical term, for it was defined by Aretaeus as a páresis-evidently the non-technical expression. Paralysis or paresis denotes the loss of function that affects motion-loss, he adds, of 'energeia': energy perhaps, but not quite; 'the thing inherent in work'."

All the terms: apoplexy, paraplegia, paresis, paralysis, here refer to the same sort of thing, or to degrees of it. 'Apoplexy is a paralysis', Aretaeus says, 'but a paralysis

\footnotetext{
1 Since this was written the student has been enabled to consult L. C. McHenry, Garrison's History of Neurology, Springfield, Ill., Thomas, 1969, pp. 370-87.

E. Clarke, 'Apoplexy in the Hippocratic writings', Bull. Hist. Med., 1963, 37, 301-14.

- References to old English usage from the Oxford English Dictionary.

- Aretaeus, the Cappadocean: The Extant Works, ed. and trans. Francis Adams, London, Sydenham Society, 1856.
} 


\section{Francis Schiller}

of the whole frame, namely of sensation, of understanding, and of movement'. It is of the highest degree and implies a poor prognosis according to Hippocrates' aphorism: 'To get over a strong attack is impossible, over a weak one, not easy'. Prognosis is also alluded to when Aretaeus again quotes the great teacher: 'When Hippocrates says, "The leg on the same side was apoplectic," he means to say it was in a deathlike ... and incurable state'. But the terminology is far from precise. Apoplexy is a 'paresis' that may affect the whole body or only part of it and as far as recovery goes, it may be total or partial. 'For what is strong apoplexy in the whole body', Aretaeus writes, 'that he [Hippocrates] calls paraplegia in the limb'.

Aretaeus of Cappadocia is a hazy figure of the second century A.D. Francis Adams, who translated Aretaeus into English, considers him a contemporary of Galen. This he deduces from the fact that, politely but jealously, neither mentions the other. In the eighteenth century paraplegia was still used for hemiplegia, although Paul of Aegina had in the seventh century coined the term hemiplegia which was subsequently preferred. ${ }^{5}$ In his chapter headed 'Paralysis', Aretaeus does not exclude the spinal cord from his consideration, but he gives no real description of the cord lesion causing bilateral paralysis which we call paraplegia. ${ }^{5}$ What he tells us is that lesions below the head 'such as at the membrane of the spinal marrow, the parts which are homonymous and connected with it are paralysed'. Head lesions themselves on the other hand, lead to contralateral paralysis. 'The cause of this is the interchange in the origins of the nerves ... Each of them passes over to the other side from that of its origin, decussating each other in the form of the letter X.' Aretaeus does not say explicitly whether paralysed limbs are either stiff or flaccid. But in a pragmatic way he does express the increase in muscle tone, for he states that the limbs 'sometimes lose their faculties while in a state of extension and cannot be brought back into a state of flexion, hence they appear lengthened.' The opposite may also happen, he adds, and then he passes on, almost in the same breath, to the state of the eyes in a somewhat confusing sentence about phthisis of the pupil (presumably miosis) versus platycoria or mydriasis. Again without a break, he speaks of the paralysed bladder: it may lose its retentive powers or, on the contrary, be unable to expel the urine.

Aretaeus gives two groups of causes for strokes: physical and mental. The physical causes are six: 'a wound, a blow, exposure to cold, indigestion, venery, intoxication.' The mental ones are 'astonishment, fear, dejection, fright (in children), occasionally unexpected joy, unrestrained laughter'. All pretty inclusive and unselective.

An almost identical list we find in Soranus, another contemporary of Galen. His work is known through a translator, Caelius Aurelianus, writing some 200 to 300 years later. All three-Soranus, Aretaeus, and Galen-are unconcerned with the pathogenesis of stroke. Practical people, they concentrate on symptomatology with a view to prognosis (apoplexy is an acute condition, paralysis chronic), and treatment. Aurelianus (a North-African of Arab rather than Negro origin) has many pages giving elaborate and sensible instructions in physical therapy, taken from

5 Paulus Aegineta, The Seven Books, trans. Francis Adams, London, Sydenham Society, 1844, vol. 1, pp. 391-93. 'When the common origin of the nerves is affected . . . the affection is called apoplexy ... but if the obstruction is in either side, it is called hemiplegia and paralysis .... When there is a remission ... [but] loss of speech continues ... a after the fourteenth day, we may ... attend to their speech .... 


\section{Concepts of Stroke before and after Virchow}

Soranus; present-day methods can hardly be called different or better. ${ }^{6}$

Galen is interesting in his distinction between karos and apoplexy. Karos (as in 'carotid') is like apoplexy (or coma as we would imply) except that in karos respiration remains unaffected. The reason, Galen thinks, why respiration is spared while intellect, sensation and movement are affected, is that in karos not the whole brain but only the 'superior' (i.e. anterior or frontal) lobe and ventricle are involved; and the cause is usually 'compression'.?

To sum up the classical view in modern terms we only need to stress that its nomenclature and symptomatology were essentially ours, but that except for strangulation and throat cutting the cerebrovascular system and its pathology were hardly considered. For this to come about, regular post-mortem inspections of the brain, concentrated thought regarding the blood and its circulation, and, above all, emphasis on etiology, were required.

Let us see what change, if any, is expressed in Hermann Boerhaave's lecture notes De morbis nervorum. ${ }^{8}$ When he used them between 1730 and 1735, Boerhaave was in his sixties and close to the end of his life. He defines the subject in the words of Aretaeus. But his list of causes also might, without much change, be used in a modern lecture-not perhaps on stroke but on coma. For 'spirits' we would have to use some other term, say oxygen. Apoplexy for him, in conformity with Hippocratic terminology, means the complete mental and physical breakdown from any cerebral cause. It is a 'stoppage of the spirits' (spiritus interceptio). The interception takes place at the origin of the medulla oblongata. In his list of apoplexies it is 'the first kind' that interests us most. It stems, he says, from a lack of spirits in the blood contained in the arterial vessels of the cerebral cortex, for this blood carries the substance necessary for giving off spirits. 'Tired blood', so to speak, for the cause is 'fatigue', defined by Boerhaave as an inability of the blood to generate spirits. This may involve cacochymia leucophlegmatica, a bad mixture due to excess of white phlegm, also the kind of thing thought to cause swelling in the brain or elsewhere. In other words the composition of the blood is at fault, the main cause of apoplexy to an iatrochemist such as Boerhaave is a dyscrasia. His next cause is anaemia, through blood loss, as in haemorrhage from, say, the uterus or the nose, or from any arterial trauma, especially one affecting the head. Thirdly he envisages mechanical causes impeding cerebral blood flow, such as 'compression of the arteries of the neck, by tumour or ligation'. In this, and the next category we now find-if only mentioned in passing - a novel factor which particularly arrests our attention. This is called stenochoria in chondrogonia arteriae, i.e. 'narrowing due to cartilaginous change of the artery'. It clearly represents our carotid stenosis due to an arteriosclerotic plaque. ${ }^{8 a}$ Other conditions where too

- Caelius Aurelianus, On Acute Diseases and on Chronic Diseases, ed. and trans. I. E. Drabkin, Chicago, University Press, 1950, pp. 566-93.

' Galen, 'De locis affectis', in Opera Omnia, ed. Carl Gottlieb Kühn, Leipzig, Cnobloch, 1824, vol. VIII (Book IV: III), p. 231.

${ }^{8}$ Hermann Boerhaave, Praelectiones de Morbis Nervorum (1730-1735), ed. B. P. M. Schulte, Leyden, Brill, 1959, pp. 300-24.

8 Boerhaave no doubt, was well acquainted with carotid stenosis from the literature. Gerhard von Swieten in his Commentaria in Hermanni Boerhaave aphorismos de cognoscendis et curandis morbis, Leyden, Verbeek, 1742, vol. III, p. 272, refers to Thomas Willis: Cerebri anatome, VII, p. 95, having the description of an occluded carotid artery causing not apoplexy but an atrocious headache, relieved by supposedly 'threefold' compensatory dilatation of the ipsilateral vertebral artery, found at necropsy. 


\section{Francis Schiller}

little healthy blood is available are finally, 'compression of the cortex by any tumour', and 'increased intracranial pressure'. The latter condition forms the link to its opposite, which is the second major and general cause of apoplexy: too much blood. For strokes may be due to any one of the conditions that cause 'plethora', mainly through obstructed venous drainage from the head, and this includes the rupture of blood vessels inside the head. Nowhere does Boerhaave claim to have introduced a radical change; nowhere does he argue with opponents or show any vexation with insoluble problems. There is no open break here, no trace of impatience with the past, no anticipation also of future discovery.

Three decades later, but also as an old man (he was nearly 80), Giovanni Battista Morgagni, devotes to the 'head', i.e. the nervous system, one whole book of the five that make up his magnum opus 'on the seats and causes of disease investigated by anatomy'. Let us recall in passing, that the reason Morgagni gave for writing this immense collection of clinico-pathological correlations was to please what we might call a graduate student. ${ }^{2}$ In epistolary form, as a kind of correspondence course, at this one young man's request and for his benefit, Morgagni poured out the lifetime total of his researches. He considers his work as an extension of Théophile Bonet's compilation published in 1679: nearly 3,000 case histories with autopsies under the macabre title Sepulchretum (the grave-yard), and the sober subtitle 'a practical anatomy'. Although critical, Morgagni does not lack in humility towards the past, and will often defend it against erroneous modern doctrines. There is a refreshing tone of candour regarding his own ignorance, and an occasional impatience with the complacency of others, especially when they fail to be rigorous in investigating both sick people and their dead organs. This intransigence is necessary if-and this is the challenge-we are to make progress in the understanding and treatment of disease. With Morgagni the challenge of the unsolved problem seriously enters the medical literature. By and large however, he is more concerned and deals more efficiently with sedibus than with causis.

As to apoplexy Morgagni prefers to start with Celsus, who antedates Aretaeus and Soranus, but also divides strokes into two kinds: total and partial. 'The former was called apoplexy by the ancients, the latter paralysis. Nowadays', Celsus adds, somewhat testily, 'I see both called paralysis'. Morgagni, no longer satisfied with such superficialities, has looked for pathological distinctions. Apoplexy is either sanguineous - the intracerebral haemorrhages described a century earlier by the Swiss doctor, J. J. Wepfer-or it is serous. 'The proximate cause' of either-Morgagni is rather noncommital-is 'a sudden diminution of the internal motions performed in the brain, to wit, when we move, think, or perceive . . . yet there are many and various causes that bring it about, some of which entirely escape the notice of the senses'. On the whole he professes ignorance, but like Boerhaave he takes it for granted that there must be something in the blood that leads to haemorrhage. ${ }^{10}$ And yet, he wonders, might not, in analogy with the belly or thorax, a ruptured aneurysm be responsible? Thus his 'worthy and learned colleague', Bernardino Ramazzini (the

- G. B. Morgagni, The Seats and Causes of Diseases investigated by Anatomy (De sedibus et causis morborum per anatomen indagatis, 1761), trans. Benjamin Alexander, 1769, New York Academy of Medicine, Hafner, 1960, vol. 1, pp. XX-XXI.

10 Ibid., Book I, Letter II, pp. 17-33. 


\section{Concepts of Stroke before and after Virchow}

first writer on occupational diseases), with symmetrical aneurysms 'no bigger than beans' between the thumb and forefinger on the back of his two hands, was 'within twelve hours carried off' by an apoplexy. A conjecture only, yet what analogy could be more natural, 'When we see these cavities in the brain and blood semi-concreted therein, or effused in great quantity into neighbouring parts ... For the substance of the brain, being very soft, yields, and admits the impelled blood, so that an apoplexy and a cavern are formed at the same time'. Brunner, (quoted from the Sepulchretum) claimed to have actually seen those aneurysms 'which seemed to have poured out this very large quantity of blood'. All the same, Morgagni owes it to himself to remain sceptical; Brunner, after all, gave no details as to location or diameter, and Wepfer was none too clear either. ${ }^{11}$

Inside the brain, those 'blood-filled cavities', incidentally, have been found in the corpus striatum or optic thalamus, or in both, or near one or both of them, with perforations and lacerations of one or both of these parts. 'We must take this as a strong evidence that here was the seat and cause of contralateral hemiplegia'. ${ }^{12}$ When nearly one hundred years earlier Thomas Willis had discovered the corpus striatum, he too had found it softened and discoloured in apoplexy-'lees of oil' being the particular hue. ${ }^{13}$

Four of his fourteen letters on the nervous system Morgagni devotes to sanguineous and to serous apoplexy. Letter number five is about the kind 'which is neither', i.e. tumours and abcesses. Letter eleven again is 'On the Palsy'. 'What convulsions ... are to epilepsy, palsy . . . is to apoplexy, ${ }^{14}$ he explains, obviously meaning a transient manifestation of a lasting condition. To us this looks like an afterthought but such was, as we have seen, the tradition. Course and prognosis are still the overriding consideration, etiology unknown and hardly looked for.

What are we to understand by 'serous apoplexy?' There is some reason to believe it refers in part to what later was identified as cerebral oedema..$^{15}$ But essentially it is the great enigma, the early pathologist's no-man's-land lying between haemorrhage and other palpable causes of brain disease, called 'apoplexy' when sudden and fatal. The effusion filling the abnormal cavities in the brain was not always red, it was by no means always blood or clot, it was colourless or just plain watery. What was it and where did it come from? Morgagni holds on to the belief that the 'serum' he saw must be the cause of the apoplexy rather than its effect or by-product. But he has a sensible reservation, indeed he is not, he says, 'in the number of those who, when they find a little water within the skull of an apoplectic person, immediately conclude that this was the cause of the disorder .... How can he be sure? He contradicts himself with an evasion. 'Water increases the disorder', he goes on cautiously, and he flips altogether in the next breath: 'Not only a great quantity, but sometimes even a little water, may be the cause of an apoplexy'. (Serum, meant the watery residue after blood, or milk, has clotted.) Even if no clot can be found, serum is still an

11 Ibid., Letter III, pp. 41-42.

12 Ibid., pp. 52-54.

18 Thomas Willis, 'Cerebri anatome' (1664), Opera omnia, Amsterdam, 1682, p. 84.

14 Ref. 9 , p. 230.

1s A. E. Walker, A History of Neurological Surgery, New York, Hafner, 1967, pp. 216-24. 


\section{Francis Schiller}

'exhalation' of blood.16

Cerebrospinal fluid? Morgagni had a lengthy and polite correspondence ${ }^{17}$ with his young admirer Domenico Cotugno in Naples (mainly about the latter's work on the semi-circular canals and their circulation which Cotugno had just discovered). But this was before Cotugno had made his little-noted yet important contribution regarding the natural presence and ways of the cerebrospinal fluid. By then Morgagni had died, sharing the classical vague belief that to find any appreciable amount of fluid, even in the cerebral ventricle, had a pathological significance. ${ }^{18}$ Morgagni was careful, however, to make a clear distinction between serous apoplexy and hydrocephalus: 'We are not treating here of the dropsy of the brain'.19 And although he called 'excellent' Boerhaave's basic distinction between 'sanguineous and pituitous apoplexy', he found the serous variety more frequent than the pituitous. And as if to confirm our doubt that phlegm on the brain could not have been frequently observed, Morgagni quotes Boerhaave's aphorism to the effect that this division is by no means perfect, since 'there are also apoplexies from serum, from atrabilis (black bile), from polypi (blood clots), and from other causes'. ${ }^{20}$

Morgagni frequently refers to his teacher, Valsalva. 'Valsalva imagined that the cause of this disorder was to be sought in the extravasated serum; and he had planned formerly, as I have learned from his papers, to make many experiments about the cause of apoplexy. For instance, whether it could be artificially brought on by throwing into the carotid arteries of beasts this or that thing; whether these arteries being tied, the animal would nevertheless feel ...'21 Unfortunately Morgagni did not follow up these projects; all the more are we impressed by this first hint that the study of strokes must start with experiments on the feeding arteries, tying them, and especially 'throwing into them this or that thing'-or embolus. Of course, strangulation of both carotid arteries had always been considered fatal.

Before we turn to the next development and hence the nineteenth century, we must briefly note that the Hippocratic and later writers, but especially Morgagni, have frequently described loss of speech in association with strokes. They did so as a matter of course, under the old term aphonia as a rule, and they saw it as a paralysis of the tongue. This is not surprising; like any other muscles those of the tongue were thought to take their nervous power from the brain. But Aurelianus (i.e. Soranus) knew that in aphonia the tongue itself need not be paralysed. He made the distinction -on which he was not bothered further to elaborate-between losing the 'orderly use of the voice (vocem non disserit), uttering sounds devoid of meaning etc.', and cases where the speech impairment evidently lay in the abnormal appearance of the tongue. ${ }^{22}$

16 Ref. 9, Letter IV, p. 64. 34-50.

${ }^{17}$ F. Aulizio, 'Rapporti tra Cotugno e Morgagni desunti da lettere etc.', Riv. Stor. Med., 1965, 9,

${ }_{18}$ He approvingly quotes Verus, a sixteenth-century author: 'in others who died of apoplexy, I saw the ventricle full of the most limpid water; whereas in a natural state it is entirely empty.' Ref.' 9 , p. 22.

${ }_{10}$ Ref. 9, p. 72.

${ }^{20}$ Ibid., p. 95.

21 Ibid., p. 65.

22 Ref. 6, pp. 568-69. For more examples and discussion: A. L. Benton, and R. J. Joynt, 'Early descriptions of aphasia', Arch. Neurol., 1960, 3, 205-22. 


\section{Concepts of Stroke before and after Virchow}

Morgagni's emphasis on the second or 'serous' cause of strokes found little following; in the minds of most physicians 'apoplexy' had become associated with haemorrhage, as it has almost to this day. But nearly sixty years later Morgagni's dichotomy acquired a new meaning. In 1820 Léon Rostan, a physician at the Salpêtrière, aroused attention by his book Recherches sur le Ramollissement du Cerveau. A second edition three years later no longer required the subtitle of 'a work in which an effort is made to distinguish by their characteristic signs the various affections of this viscus'. Happily 'the effort' had been crowned with success. Rostan claimed that the discovery of softening was 'toute moderne'. While 'several persons may have seen it at the same time, no author had dealt with it ex professo'. True, there had been examples of it in Morgagni's work under the heading of serous apoplexy; Rochoux in his monograph on apoplexy (1814) had used the term; Abercrombie (1819) and others had spoken of it, but only in passing. ${ }^{23}$ Indeed Rostan estimated softening to be 'the most frequent cerebral lesion'. In contrast to apoplexy, i.e. haemorrhage, from which he had seen recovery with or without paralytic defect, he declared softening fatal, and so reversed the true state of affairs. But they may coexist, he said. Occasionally-among many other observations-he had noticed one pupil fixed and dilated. And he was one of the first again to draw attention to the 'invincible contracture of the affected side', in what he called 'the second stage' of softening. (The first, or prodromal stage was characterized by dizziness, headaches, etc.) The truly novel and controversial aspect of Rostan's study, however, was a negative one: it was his rejection, cautious but firm, of the current notion that the universal cause of stroke was an 'encephalitis', his denial that it was inflammatory. ${ }^{24}$

The most widely-read advocate of the inflammation or 'irritation' that underlies softening-in the brain or elsewhere-was François Lallemand at Montpellier. To appreciate the bitterness of the controversy between him and Rostan it is enough to note the total suppression of Rostan's name in Lallemand's Letters about the Brain, published in $1824 .{ }^{25}$ We also see contemporary writers take sides and insist on the sharp difference of opinion between Rostan and Lallemand. Thus Rostan's teacher Andral argues in his Précis d'Anatomie pathologique of 1829 that 'Lallemand's "irritation" will first convince you, but then raise your doubts, which Rostan will confirm. In ramollissement you just do not see the congestion that is required for speaking of inflammation; nor is white softening associated with pus, as Lallemand claims'. Softening according to Andral, is 'a diminution of cohesion in the tissues', further defined as 'a modification of nutrition due to changes in the consistency of the molecules that normally must constitute the different solids'. Softening is 'a

${ }^{23}$ Léon Rostan, Recherches sur le Ramollissement du Cerveau etc., Paris, Béchet, 1820 (2nd ed., 1823), p. 4.

24 Ibid., pp. 332-33; 449-72. But if not inflammatory, what was it? Rostan did not know; thrombosis did not occur to him. Yet much earlier, and before the vitalist theories of irritation and inflammation had been elaborated, 'obstruction' of blood vessels had been categorized by Boerhaave as one of the causes of disease. In his Commentaries on Boerhaave's Aphorisms, von Swieten (ref. 8a, vol. I, p. 66) devotes some space to 'polyps' (as thrombi found in the heart and elsewhere were called); he gives as his authority Marcello Malpighi, De polypo cordis dissertatio. Here, (Opera omnia, Leyden, Vander, 1687, vol. II, p. 316) we find: 'In apoplexy likewise, as many observations show, polyps coalesce in both the major and the minor vessels that course along the cerebral meninges.'

${ }_{25}$ François Lallemand, Recherches anatomico-pathologiques sur l'encéphale et ses dépendances, Paris, Béchet, 1824. 


\section{Francis Schiller}

perversion of the nutritive process (acte)'. 'Perhaps', Andral speculates, it really is 'a senile destruction analogous to the gangrene of old age'. ${ }^{26}$ But we must realize that Andral nowhere associates gangrene with vascular occlusion.

There is no doubt that Andral's scepticism (he said elsewhere that inflammation 'was a metaphor and ought to be withdrawn like a disused coin'), ${ }^{27}$ and even more Rostan's bold refusal to accept inflammation as the most frequent, not to say the sole cause of softening, were significant departures from a pervasive trend. The eighteenth-century elaborations on Celsus' famous rubor et tumor cum calore et dolore theme held sway even throughout the first half of the nineteenth centuryat least on the Continent, if less so in England. ${ }^{28}$ 'It has been the opinion of some Pathologists that every diseased structure is the consequence or the effect of inflammation', wrote the editor of Matthew Baillie's Works in $1825 .{ }^{29}$ Baillie himself, the numerous editions of whose handy first English textbook of morbid anatomy began in 1795, thought inflammation was not very common in the brain "when no external injury had been applied to the head'. ${ }^{30}$ In conformity with current opinion and experience Baillie added, however, that trauma did lead to inflammation. But the red colour denoting congestion and due to a 'great many small vessels, which are filled with blood', this red colour was 'seldom very intense' unless trauma was present. Another colour-pale yellow-comes to mind when we read on where Baillie-John Hunter's nephew and disciple-says that some brains, in one part, may be so 'very soft' that they acquire 'nearly the consistence of a custard'. Dr. Hunter, he says, had observed this soft consistence 'near the lateral ventricles . . . in cases of fatuity ... . advanced in life, and also combined with effusion of blood in apoplexy . . . Effusions of blood leave cavities containing a serous fluid.'31

More striking is Baillie's discovery that haemorrhage, if not plain softening of the brain, is associated with the hardening of its arteries: 'It is very common . . . in persons advanced in life, to find the trunks of the internal carotid arteries upon the side of the sella turcica very much diseased, and this disease extends frequently more or less into the small branches. The disease consists in a bony or earthy matter being deposited in the coat of the arteries, by which they lose a part of their contractile and distensile powers, as well as of their tenacity'. This is 'likewise found in the basilar artery and its branches'. And he concludes that without this 'diseased alteration . . . effusions of blood . . . would probably be much more rare'. ${ }^{32}$ With some excitement Baillie also records two 'aneurysms of the internal carotid arteries on the side of the sella turcica ... one . . . about the size of a cherry, and the other was somewhat smaller.'s3

The finding of what we call arteriosclerosis is, as such, very much older. We have heard Willis and Boerhaave speak of cartilaginous change in the carotid artery.

${ }^{26}$ Gabriel Andral, Précis d'Anatomie pathologique, Paris, Gabon, 1829, vol. II, pp. 806-7; vol. II, pp. 195-214.

i7 Ibid., vol. I, pp. 9-10.

${ }^{28}$ L. J. Rather, Virchow und die Entwicklung der Entzündungsfrage im 19ten Jahrhundert (Verh. 20. Internat. Kong. f. Gesch. d. Med., 1966), Hildesheim, Olms, 1968.

20 Matthew Baillie, The Works, collected by James Wardrop, London, Longman, 1825, vol. 2, p. xxiv.

20 Ibid., p. 439.

81 Ibid., p. 442 .

32 Ibid., pp. 453-54.

ss Ibid., p. 456. 


\section{Concepts of Stroke before and after Virchow}

About 'ossification' of the aorta one can read, if only briefly, in Fallopio (1575), Harvey, de le Boë, Bartholin, Willis, Malpighi, Cowper, Haller, and Hodgson. ${ }^{34}$ Morgagni's 'ossification' of the coronary vessels associated with chest pain is famous. P. H. Bérard, a contributor to the Dictionnaire de Médecine of 1833, stated under the heading 'Osseous, steatomatous, atheromatous degenerations, ulcers, and rupture of arteries', that there was 'nothing more common, especially in persons of advanced age, than deposits of calcium salts in the thickness of arterial walls . . . indifferently called ossification, concretions, calcareous deposits'. Steatomatous, 'fatty' was Scarpa's term;34 he was Morgagni's successor. Also quoted in the Dictionnaire is an intrepid student, a Monsieur Allibert; in his doctoral thesis of 1828, two decades before Virchow, he had dared to maintain that clot might form spontaneously in the arteries and give rise to inflammation secondarily. An untenable position, Bérard thinks-except, after all, perhaps occasionally! The term arteriosclerosis, forgotten until Virchow revived it, first appeared in a text of pathological anatomy, published in 1829. The author, holder of the first French chair in this field, was Johann Georg Christian Friedrich Martin Lobstein in Strasbourg. Lobstein described the arterial thickening and that 'yellow puree-like, uneven, knobby matter, perfectly similar to the surface of those bones affected with osteosclerosis'; it was not 'phlogistic', i.e. not inflammatory, but: 'I can neither give its cause nor its effect . . . 35

Now Baillie's hunch that cerebral haemorrhage might be associated with this arterial change did not amount to the sort of solid foundation upon which etiological reasoning is safely built, accepted, and finally taught. That hardening of the arteries leads to softening of the brain was not implied before the $1830 \mathrm{~s}$, and even then far from being generally believed. But it was the beginning of the notion that stroke is primarily the result of vascular as opposed to blood disease, and mechanical rather than inflammatory.

In 1837, Bizot from Geneva, an adept of Louis and the statistical method, demonstrated atheroma and calcification in the arteries of 157 subjects $;^{36}$ in 1831 , the honorary president of Bizot's Société Médicale d'Observation, the distinguished surgeon Jules Cloquet, had illustrated a vascular occlusion caused by such a lesion. ${ }^{37}$ Similar illustrations were in Bright's book of the same year. ${ }^{28}$ Valentin in Berne, former assistant of Purkyně and early microscopist, refuted in 1836 the notion of 'bone' lodged in the arterial wall in favour of 'organized calcareous deposits' ${ }^{39}$ Another Swiss professor, also German born, Karl Ewald Hasse, in his monograph on pathology of circulation and respiration (1841), ${ }^{40}$ like many before him, spoke of 'excessive deposi-

24 E. R. Long, 'The development of our knowledge of arteriosclerosis', in E. V. Cowdry, Arteriosclerosis, New York, Macmillan, 1933, pp. 19-52.

${ }_{22}$ Antonio Scarpa, Degli Aneurismi, Opere, Florence, Tip. della Speranza, vol. 3, p. 478.

${ }^{25}$ Jean Frédéric Martin Lobstein, Traité d'Anatomie pathologique, Paris, Levrault, 1829, vol. II, ch. VI, S 1075, De l'épaississement des artères ou de l'artériosclérose, pp. 550-66, Osteosclerosis here (ibid., p. $103 \mathrm{ff}$.) is any form of osseous hypertrophy with induration, such as our Paget's disease.

${ }^{26} \mathrm{~J}$. Bizot, 'Recherches sur le coeur et le système artériel chez l'homme', Mem. Soc. méd. Observation, 1837, 1, 262-411.

37 Jules Germain Cloquet, Pathologie chirurgicale, Paris, 1831, Plate II.

28 Robert Bright, Reports of medical cases .... illustrating ... diseases by reference to morbid anatomy ... Brain and nervous system, London, Longman, 1831, vol. 2.

${ }_{30}$ Gabriel Gustav Valentin, Rep. Anat. Physiol., 1836, 1, fasc. III and IV, p. 317, quoted by the following.

10 Karl Ewald Hasse, An Anatomical Description of the Diseases of the Organs of Circulation and Respiration, trans. W. E. Swaine, London, Sydenham Society, 1846, ch. III, p. 72, See also ref. 34. 


\section{Francis Schiller}

tion of calcareous products between the walls of arteries, a process sometimes associated with inflammation which leads to the formation of an adhesive plug and eventually to obliteration. Atrophy of the part involved is the common result (uterus and spleen).' It was practically impossible to do without inflammation-tying an artery produces it, Hasse said-and he does not mention the brain being so affected.

Another condition, gangrene, which commanded a great deal of medical and surgical attention now also began to shape the concept of stroke. Gangrene came in two forms: traumatic and senile. Severely wounded limbs, of course, became gangrenous more often than not, and the ever-present inflammation was registered while infectious micro-organisms were unknown. Even gangrene of old age appeared inflammatory in nature. But Andral had begun to consider it, vaguely, as a nutritional defect, and apt to cause softening. Andral's influence was great in England where we find the same idea expressed in John Abercrombie's popular Pathological and Practical Researches on Diseases of the Brain and Spinal Cord, first published in 1828. Here the 'third class' of 'paralytic cases' of apoplexy, i.e., without coma and death, is subdivided into 'I. Serous effusions, II. Small extravasations of blood, III. Ramollissement, IV. Inflammation'. Ramollissement, as he still deferentially calls it, Abercrombie considers 'analogous to gangrene'. What is more, he considers it due to 'failure of circulation', this, in turn, is due to 'ossification of arteries'.41

Perhaps this was the first time the problem had been fully seen in its 'true' perspective-that is, the one accepted today. Ten years later Robert Carswell in his authoritative Pathological Anatomy of 1838, the English counterpart to Cruveilhier's work, endorses Abercrombie without mentioning him. Carswell's book with fine coloured illustrations of the 'elementary forms of disease' categorizes the whole of pathology into Inflammation, Analogous Tissues, Atrophy, Hypertrophy, Pus, Mortification, Haemorrhage, Softening, Melanoma, Carcinoma, and Tubercle. Mortification, gangrena senilis is not an inflammation of the arteries, he writes, but has an obstructing cause, viz. fibrous, fibro-cartilaginous, osseous tissue. 'Inflammation terminating in softening is sometimes met with ... surrounding the effused blood'-he grants that much to the old ideas. As to softening or ramollissement he recalls the 'recent' Rostan and Lallemand dispute and concedes that 'the subject is of great interest and importance'. Softening of the brain in his opinion, may result from (1) inflammation, (2) obliteration of arteries, (3) modification of nutrition. Lallemand's opinion that softening always is an inflammation, he admits, is still 'most generally received'. But it is 'as far from the truth' as Rostan's ideas are 'ambiguous and inconclusive'. Softening, he adds 'has been conjectured to originate in ossification of the arteries, yet even M. Rostan . . . has not given a single case . . . at autopsy'. ${ }^{42}$ Carswell does not recall that the idea of softening of the brain caused by hardening of the arteries was Abercrombie's, not Rostan's.

Carswell, incidentally, in his chapter on haemorrhage points out the claims then made regarding 'the relations between the seat of the effused blood and the paralysis

41 John Abercrombie, Pathological and Practical Researches on Diseases of the Brain and the Spinal Cord, Philadelphia, Carey, Lea \& Blanchard, 1836 (2nd American; from 3rd Edinburgh ed.), p. 204.

${ }^{22}$ Robert Carswell, Pathological Anatomy, Illustrations of the Elementary Forms of Disease, London, Longman, 1838. 


\section{Concepts of Stroke before and after Virchow}

of particular organs'. These were: thalamus for the superior extremity, corpus striatum for the inferior extremity, anterior lobes for speech. He does not think these 'special relations' have 'as yet been established'; Bouillaud, the believer in encephalitis who had first claimed such special relations in $1825,{ }^{43}$ is not quoted by name.

On the Continent it was not the English School but rather Cruveilhier who dominated the field in the next decade-the 1840s-when Virchow entered it. And with Cruveilhier, not Rostan's scepticism prevailed but Lallemand's 'most generally received' notion that strokes generally had an inflammatory origin. In Cruveilhier's definition ramollissement was a 'capillary apoplexy'. It must be realized that he considered the capillaries to be part of the venous system and that circumscribed capillary stasis or congestion was due to some-undefined-'irritation'. In other words Cruveilhier elaborated the traditional view that the first change in any equilibrium or any revolution in society-is due to irritation. Ubi stimulus, ibi affluxus was an old adage, its origin lost in the mist of time. The second stage consisted in pathological secretion, coagulable lymph, pus, caseation and such. Cruveilhier apostrophizes active rupture of cerebral arteries as 'armchair reasoning'.44 Yet he pays a good deal of attention to arteries showing 'cretaceous' changes. And he discusses at length the pulpy or pultaceous ramollissement, 'incontestably gangrene, i.e. partial [local] death whatever the cause'. Also 'the cretaceous changes . . . in the arteries of old women at the Salpêtrière have not escaped me. Are they not sometimes, with their shrunken lumen, the cause of arterial occlusion-both through themselves', and, Cruveilhier hastens to add, 'through the arteritis obliterans that sometimes follows?'45 Unlike Rostan and Lallemand, he has seen recovery from softening. So as to support his own observation, he takes pride not only in having quoted Haller on gangrene of an amputated limb where small arterial branches had 'degenerated to the hardness of bone' (in the edition of 1842), but also in an opinion he had ventured long ago: about blood clot in the heart. It was 'extremely likely that fragments would be thrown towards the extremities in a great number of cases ... also from the right ventricle into the pulmonary circulation'. He was not impressed by the novelty of 'a doctrine which had been around for a long time, in practice rather than in science. But it has taken a new turn since the important work by $\mathbf{M}$. Virchow who has recently given the name of emboli to these clots. I recall the case of a person . . . with a needle in his heart . . . clot around it . . . gangrene of the lower limbs... A And he goes on to say that emboli are, 'properly speaking, impossible to prove and hard to distinguish from the obliterating arteritis which they inevitably must cause $\ldots{ }^{46}$ In other words the perennial rebuke about the good not being so new and the new not being much good. Even in 1862, after fifteen years, you could not expect Cruveilhier to give unreserved recognition to Virchow's epoch-making paper on embolism published in 1847.

\footnotetext{
43 Jean Baptiste Bouillaud, 'Recherches cliniques propres à démontrer que la perte de la parole correspond à la lésion des lobules antérieurs du cerveau etc.', Arch. gén. Méd., 1825, 8, 25-45, Traité... de l'Encéphalite ou Inflammation du Cerveau ... Paris, Baillière, 1825.

44 Jean Cruveilhier, Traité d'Anatomie pathologique générale, Paris, Baillière, 1862, vol. IV, p. 216.

45 Ibid., pp. 266-67, 285-86.

16 Ibid., pp. 290-91. Presumably unaware of Virchow's work, W. S. Kirkes published three cases of cerebral embolism: 'On some of the principal effects resulting from detachment of fibrous deposits from the interior of the heart', Trans. med.-chir. Soc. Lond., 1852, pp. 281-324.
} 


\section{Francis Schiller}

Not long before that, the great publishing event of the 1840s in the field of pathological anatomy had been Rokitansky's four-volume manual. In Vienna Rokitansky had presumably performed more autopsies than any single man before him. As to haemorrhagic apoplexy Rokitansky insisted on a novel concept: its close mechanical association with heart disease. Many apoplexies were due to congestion, or dilatation of the right ventricle. Haemorrhage, more importantly, may secondly be related to hypertrophy of the left ventricle and hence to an increased 'impulse'. (High blood pressure at that time had neither been taken seriously nor, of course, had it been seriously taken.) Thirdly, brittle arteries were contributory to haemorrhage either alone or in combination with the first-mentioned two factors. A fourth factor was the 'anomalous condition of the blood'. In such instances-the cyanosis was a 'venous crasis', a chemical change associated with pulmonary congestion (carboxyhaemoglobin was not known). Venous stasis has not survived as an important cause of apoplexy, but important, we think, was yet another anomaly considered by Rokitansky to be 'of the blood': the condition first called 'arteriosclerosis' by Lobstein in the 1820s. Rokitansky had the idea that the 'so-called ossification' of the arteries resulted from 'the accumulation of an inner membrane upon the vessel by deposition from the arterial blood'. An additional chemical agent from the blood was absorbed by the vessel wall, its elements constituting the atheroma of the artery, especially its fat. Andral and Gavarret had written about that, and Rokitansky expressed regret for having no more information available. Lastly he mentioned, as an etiology, atrophy of the brain in advanced age-today we think of this in terms of decreased support for the arteries. To Rokitansky atrophy was not a mechanical factor; these, he says, are more important than atrophy.

Much of his masterly presentation of softening nearly corresponds to the presentday gross descriptions of haemorrhagic infarct and ischaemic necrosis. Encephalomalacia, as he called it, may be white-as in 'serous apoplexy' by which he understood cerebral oedema. Red softening was inflammatory in nature. The most common variety both to him and to us was yellow softening. He declares it to be definitely non-inflammatory, but it may accompany inflammation or haemorrhage. Where Rokitansky could see no cause-and he had no place for vascular occlusion-he found yellow atrophy idiopathic, 'quite problematical', and he assumed an underlying 'chemico-pathological process', a crasis. ${ }^{47}$

Rokitansky was close to forty when his work appeared; three years later, in 1847, Virchow was still only 26. This was the year before he had to leave Berlin for his liberal activities on the barricades; he showed even more temerity perhaps when he attacked 'acute inflammation of arteries' in the first volume of the Archiv für pathologische Anatomie, Physiologie und klinische Medizin-Vichow's Archiv.' He had just founded it with a colleague, because two previous papers of his, directed against the inflammatory theory of thrombosis, had been rejected by another journal.48 With characteristic petulance Virchow ridicules the degree of confusion which the

${ }^{17}$ Carl Rokitansky, A Manual of Pathological Anatomy (1824-1844), London, Sydenham Society, 1856, vol. III, pp. 399-419.

18 Rudolf Virchow, (a) Gesammelte Abhandlungen zur wissenschaftlichen Medizin, Frankfurt, A. M. Meidinger, 1856, p. 478, fn. (b) See also 'Erinnerungsblätter', Arch. path. Anat. Physiol., 1852, 4, $541-48$. 


\section{Concepts of Stroke before and after Virchow}

subject of inflammation has reached. Already his gunsights are levelled at Rokitansky, mentioned not by name, only by his 'doctrine of crases'. 'There is perhaps none', Virchow says, 'where the results of observation are buried under such a gaudy mixture of seemingly empirical views, a priori speculations, and clinical arbitrariness. Barely half a century has passed since arterial inflammation began to be discussed in earnest; yet for all the theoretical and hypothetical viewpoints current today the argument might as well have arisen between Machaon and Podalirios [the doctors of the Iliad]. It would be more than unrewarding for me to discuss every arbitrary interpretation of the facts, every dream of extravagant phantasists .... Above all, in thrombosis inflammation is a secondary event, due to a chemical alteration of the thrombus. He has discussed this in two previous papers. It has been shown experimentally, he says, by Magendie and by Carswell, with strings placed into the lumen of blood vessels. Carswell was also the first to prove that yellow softening of the brain follows arterial obliteration, and that it was not inflammatory. Now, in contrast to that kind of obliterating clot we find another kind. Here there is either no essential change in the vessel wall and its surroundings, or this is ostensibly secondary. I feel perfectly justified in claiming that these clots never originated in the local circulation but that they are torn off at a distance and carried along in the blood stream as far as they can go'.99 If the concept was not novel, at least it was for the first time supported by a wealth of documentation. He had seen examples of embolization in every organ, including the brain-all without signs of inflammation. (Paradoxically, by the way, Virchow remained hesitant about extending this very concept of his to the bloodborne metastases of cancer.)

Virchow's role must be seen in the decisive switch from the vitalist concept of inflammation to the demonstrable fact of a mechanism, as fundamental and modern as plumbing. For several years he continued to write about the distinction between phlebitis and arteritis ('phlogosis') on one hand, thrombosis on the other. ${ }^{50}$ Reviving Lobstein's term 'arteriosclerosis', quoting Rayer (1823), Bizot (1837), and others, Virchow considers this 'simple fat metamorphosis to be one of the most common changes'. In reading on, however, we are in for a surprise: Virchow expresses the belief that these arteriosclerotic changes-degenerative to us-are inflammatory in nature. He coins the term 'endarteriitis deformans sive nodosa'. However, his idea of inflammation is not the common vascular one: as the prospective father of cellular pathology, he insists that the atheromatous process is 'parenchymatous', not 'exudative'; like any other inflammation it takes place in 'epithelial cells'. He will concede that there may be deposits on the intima, but they are not an additional 'inner coat' à la Rokitansky, only blood clot that is being laid on as an 'adventitious companion of the thickening'. In his opinion such atheromatous changes, while they also may contribute to blood vessel fragility, are not the direct cause of apoplectic haemorrhage: 'Paget is not quite right if he so considers them'.

Virchow's work on problems of vascular and inflammatory pathology was con-

10 Idem., 'Ueber die akute Entzündung der Arterien', Arch. path. Anat. Physiol., 1847, 1, 272-378. (Also in Ges. Abh. See above, pp. 380-450.)

${ }^{30}$ Idem., Ref. 48a; p. 478 ff; 492-96; 500-4. Virchow's classification of apoplexy was (a) sanguinea, (b) ischaemica (his term). Of ischaemic apoplexy, embolism was the most common cause: in the middle cerebral, the anterior cerebral, the carotid, or the vertebral artery. Ibid., p. 710. 


\section{Francis Schiller}

tinued, crowned, refuted to some extent, and superseded, by his extraordinary student, Julius Cohnheim. When we use 'cerebral infarct' as the more learned synonym for 'stroke' we essentially follow Cohnheim's concept based on his elegant arterial injections of wax globules, designed to lodge as emboli in the frog's tongue. Such embolization, when it caused an injury at all, produced two kinds of lesions, lesions that for nearly one hundred years now have been recognized as 'ischaemic necrosis' on one hand, 'haemorrhagic infarct' on the other. Now Cohnheim would not extend 'infarct' to cover 'ischaemic necrosis', as we usually do. He strictly distinguished between the two forms of cerebral softening. Necrosis, cell death, was the straightforward outcome of starvation due to the cessation of blood supply. 'Infarction' to him still had the original sense of 'stuffing'. In this case the stuffing was 'haemoptoic': haemorrhagic, that is. For he observed two successive events: first, the retrograde filling and the distention with blood of the venous and capillary void distal to the plug; second, the subsequent diapedesis of red corpuscles through the vessel walls, damaged secondarily by the loss of their normal blood supply. He saw blood seeping into the tissue, while no actual haemorrhage, no actual break of blood vessels had occurred. This phenomenon was not confined to embolization: any arterial occlusion may produce a haemorrhagic infarct. ${ }^{51}$ Without saying so, Cohnheim gave here the mechanism to account for the congestion Cruveilhier had ascribed to irritation. The diapedesis of blood elements through invisible, protoplasmic openings in the capillary walls is, of course, Cohnheim's most famous and controversial physiopathological contribution. Here he was dealing with erythrocytes, but a few leukocytes characteristic for inflammation, were at a later stage of infarction also seen to escape. The year was 1872; had Cohnheim been given to citing predecessors (other than Virchow to whom he dedicated his study on embolism) he might have reminded his readers that 'cellular infiltration' in cerebral softening had been described and discussed, if not explained, thirty years earlier by Durand-Fardel in Paris. ${ }^{58}$ Durand-Fardel (believer in the inflammatory theory) incidentally deserves credit for having in 1843 placed great emphasis on the 'much neglected contracture', or spasticity, which to us has become the hallmark of the hemiplegic limb.53

In his work on embolism Cohnheim gave an account-far more balanced than he is credited with and hardly bettered by modern studies-of the relative importance that end-arteries have in producing, and anastomoses have in overcoming, cerebral infarction. ${ }^{54} \mathrm{He}$ also acquainted the profession with paradoxical embolism due to communications between the right and left cardiac ventricle.

In this and the following decades detailed investigations into the vascular anatomy of the brain were fostered by contemporary interest in cerebral localization. Henri Duret, on Charcot's team at the Salpêtrière, led the way in $1874 ;^{55}$ important con-

\footnotetext{
61 Julius Cohnheim, Untersuchungen über die embolischen Processe, Berlin, Hirschwald, 1872.

52 Maximilien Durand-Fardel, 'Mémoire sur la réparation ou cicatrisation des foyer hémorrhagiques du cerveau', Arch. gén. Méd., 1844, ser. 4, 5, 35-50.

"s Idem., 'De la contracture dans l'hémorrhagic cérébrale', Arch. gén. Méd., 1843, 2, 300-11.

b4 Ref. 51, pp. 72-73.

ss Henri Duret, 'Recherches anatomiques sur la circulation de l'encéphale', Arch. Physiol., Paris, 2e ser., 1, 60-91, 313-353, 664-693.
} 


\section{Concepts of Stroke before and after Virchow}

tributions followed by Beevor in $1908,,^{56}$ by Foix, ${ }^{57}$ and by Pfeifer ${ }^{58}$ in the 1920 s. A major part of the growing specialty that came to be known as Neurology was based on recognizing, through post-mortem verification, the topographical significance of any given deficit in the patient's motor or sensory functions. In a large measure this was made possible by the frequent occurrence and the stationary character of 'cerebro-vascular accidents'. ${ }^{59}$ The origin of the clot that is propelled along the blood stream, to become an embolus at a distal site, was for some time limited to a diseased heart or, in paradoxical embolization, a thrombosed vein. At first, the arteries narrowed by arteriosclerosis were thought to give rise to occlusion and infarction only at the site of the narrowing. But the two processes combined-the embolic plug derived from a narrowed and ulcerated carotid wall in the neck-appeared as a new concept when C. M. Fisher advanced it in $1951 .{ }^{60} \mathrm{It}$ has since dominated the renascent interest in strokes that began with a new diagnostic method: arteriography. Emboli, accordingly, may be the cause of transient ischaemic attacks, perhaps even lead more often than had been realized to permanent infarction. In this context Miller Fisher reminded his readers of the neglected post-mortem observations published by H. Chiari in 1905. There, out of seven patients with 'arteriosclerosis nodosa' or 'endarteriitis chronica deformans', resulting in primary thrombosis at the carotid bifurcation, four had died of secondary cerebral embolization. ${ }^{61}$

We have seen how softening of the brain gained understanding throughout the nineteenth century. Haemorrhage on the other hand, since Wepfer and the seventeenth century the core of the apoplexy problem - and indeed the prime killerparadoxically proved not only second in frequency but also much harder to elucidate. Of the two, haemorrhage is the catastrophe that even more thoroughly destroys the evidence of its origin. Since Andral and Rokitansky, hypertrophy of the left cardiac ventricle was increasingly associated with stroke, with Bright's disease, and with

${ }^{56}$ Charles Edward Beevor, 'On the distribution of the different arteries supplying the human brain', Phil. Trans. R. Soc., 1908, 200B, 1-55.

${ }_{57}$ Charles Foix and A. Masson, 'Le syndrome de l'artère cérébrale postérieure', Presse Méd., 1923, 32, 36. Idem., 'Re anterior cerebral art', Encéphale, 1925, 4, 209 (with P. Hillemand), Rev. neurol., Paris, 1925, 1, 160-79.

${ }_{58}$ R. A. Pfeifer, Die Angioarchitectur der Grosshinrinde, Berlin, Springer, 1928.

${ }^{50}$ That rather blurry and pompous piece of nomenclature must have issued from the well-meant tendency to soften the blow to patients and their relatives, also from a desire to replace 'stroke', a pithy term that may sound unscientific and lacking gentility. 'Cerebrovascular accident (CVA)' can be traced to the early 1930 s-between 1932, to be exact, when it was still absent from the 15th edition of Dorland's Medical Dictionary, and the following edition of 1936 where it first appeared.

${ }^{80}$ M. Fisher, 'Occlusion of the internal carotid artery', Arch. Neurol. Psychiat., 1951, 65, 346-77.

61 Hans Chiari, 'Ueber das Verhalten des Teilungswinkel der Carotis communis bei der Endarteriitis chronica deformans', Verh. dtsch. path. Ges., 1905, 9, 326-32. Trans., and other historical sidelights, in A. J. Gunning, et al., 'Mural thrombosis of the internal carotid artery and subsequent embolism', Quart. J. Med., 1964, 33, 155-95. Note also this comment on transient ischaemic attacks (and the postal service of a bygone day): ' $I$ have had a letter in the evening from a man who at 9 a.m. could not button his shirt collar ..., from Sir William Osler, 'Transient attacks of aphasia and paralyses in states of high blood pressure and arteriosclerosis', Canad. Med. Assoc. J., 1911, 1, 919-26.

The role in 'apoplexy' of the occluded or diseased carotid artery is implicit in its name (karos, ref. 7); it was mentioned by Boerhaave (ref. 8, 306) and by Willis before him (ref. 8a). The vessel might evidently also be tied with impunity (Sir Astley Cooper, "Account of the first successful operation performed on the common carotid artery, for aneurysm [of the neck], in the year 1808: with the post-mortem examination in 1821', Guy's Hosp. Rep., 1836, 1, 1853-1858.) Even both carotids were ligated 'within a short interval of each other, with the most favourable result (Kuhl, Med. Gaz., 1835); as reported by Hasse, ref. 40, p. 70. 


\section{Francis Schiller}

arteriosclerosis. ${ }^{62}$ In the second third of the nineteenth century Ludwig and Marey ${ }^{63}$ began to measure blood pressure. It is high in some cases of thrombosis, high in nearly all patients with intracerebral haemorrhage. But healthy blood vessels when subjected to excessive pressure do not burst any more than they allow to form clots. Charcot and Bouchard, like many others, belittled arteriosclerosis as a cause of haemorrhage. They found haemorrhage most frequently associated with tiny aneurysms just visible to the naked eye, attached to the small arteries of the brain. ${ }^{64}$ Hence Charcot declared these miliary aneurysms to be different from the miscroscopic widening of capillaries described, also in 1866 and in Paris, by Laborde. Laborde called his kind moniliform enlargements, ${ }^{65}$ and considered them the cause of softening rather than of haemorrhage. (Neither view is generally accepted today.) Laborde also drew attention to what he called lacunae pisiformes; multiple softenings mainly in the basal ganglia. ${ }^{66}$ Lacunes received their clinical elaboration-dementia with symptoms resembling Parkinson's disease-as état lacunaire by Pierre Marie in 1901.67 Although Marie makes a distinction, presumably the identical appearance had been referred to as état criblé by Durand-Fardel in 1873 and before..$^{68}$

We have stressed the mechanical role of the vessels in the developing ideas about stroke, but what of the blood itself? Before Virchow had won his victory for solidism over humoralism in pathology (a victory decisive for nearly one hundred ensuing years), blood was considered the universal generator in animal biology, hence also the universal culprit in disease. 'Quite a special juice', in science and fiction, so special in fact, that the devil in Goethe's Faust will have none other than blood for signing his pact. We can drop here only a few names taken from the milestones lining a very long road, to arrive at the idea that circulating blood is just another tissue, not 'special' at all, merely specialized for transportation, incapable even of reproducing its own kind. The story of blood and tissue respiration has been admirably told by one of its most distinguished contributors, David Keilin, the discoverer in 1925 of cytochrome $\mathrm{C}$, the enzyme responsible for the transfer of oxygen. ${ }^{69}$

${ }^{\circ 2}$ Ref. 26 and 47. Also Antoine Portal, Observations sur la Nature et le Traitement de l'Apoplexie et sur les Moyens de la Prévenir, Paris, Crochard, 1811; and George Burrows, On Disorders of the Circulation and of the Connection between Affections of the Brain and Diseases of the Heart, Philadelphia, Lee \& Blanchard, 1848.

${ }_{63}$ G. Pickering, 'Systemic arterial hypertension', in A. P. Fishman and D. W. Richards, Circulation of the Blood-Men and Ideas, London and New York, Oxford University Press, 1954, pp. $487 \mathrm{ff}$.

sean Martin Charcot and Charles Bouchard, 'Note sur une altération des petites artères de l'encéphale qui peut être considérée comme la cause la plus fréquente de l'hémorrhagic cérébrale', Soc. de Biol., March 1866; and Charcot: Oeuvres complètes, Paris, Progrés. Méd., 1890, vol. IX, p. 3-72.

os Jean Baptiste Vincent Laborde, Le Ramollissement et la Congestion du Cerveau principalement considérés chez le Vieillard, Paris, Delahaye, 1866, p. 209. (Charcot, loc. cit., says they were first described by Hasse and by Kölliker.)

Aneurysms of the large intracranial arteries had been given as the source of intracranial bleeding ever since the end of the seventeenth century, in the Sepulchretum, quoted by Morgagni (ref. 11). But extra-cerebral intracranial haemorrhage, although included in the classical definition of 'apoplexy', does no longer fit the medical connotation of 'stroke'. For the history of subarachnoid, subdural, and extradural bleeding see A. E. Walker, A History of Neurological Surgery, New York, Hafner, 1967, pp. 236-38; and 250-69 (H. C. Johnson).

60 Ibid. (ref. 65), p. 94.

-7 Pierre Marie, 'Des foyers lacunaires de désintegration et de différents autres états cavitaires du cerveau', Rev. Méd., 1901, 21, 281-98.

88 Charles Louis Maxime Durand-Fardel, Traité pratique des Maladies des Vieillards, Paris, Baillière, 1873, p. 12. See also W. Hughes, 'Origin of lacunes', Lancet, 1965, ii, 19-21.

${ }^{69}$ David Keilin, The History of Cell Respiration and Cytochrome, Cambridge, University Press, 1966. 


\section{Concepts of Stroke before and after Virchow}

Briefly, the story is that death has always been known to follow starvation and dehydration, strangulation, asphyxiation, and excessive bleeding. Hence food and water, blood and air are indispensable to life. Natural spirits or blood are produced from food and water in the liver, vital spirits from the combination of blood and air in the heart and lungs, to be refined as animal spirits in the brain. But Galen refutes Erasistratus: there is no air in the arteries. After Leeuwenhoek discovers the erythrocyte, Harvey the two circulations, and Malpighi the capillaries (in the seventeenth century), Priestley, Lavoisier, and Spallanzani (the generation following Morgagni's in the eighteenth), establish the physico-chemical fundamentals of respiration. The relationship of oxygen and carbonic acid to the blood and tissues emerges from the work of Claude Bernard, Ludwig, and Pflüger (in the second half of the nineteenth century). MacMunn and Hoppe-Seyler put forth the oxygen-binding role of the blood pigment still before Cohnheim's death. At the same time a flurry of excitement fans the mind of Broca, of Lombard, of Schiff involving them separately in measuring the heat generated in the brain by mental activity and altered by vascular pathology. ${ }^{70}$ Schiff was the teacher of Mosso; ${ }^{71}$ Roy, who worked with Sherrington on cerebral circulation, the pupil of Mosso, at the end of the nineteenth century. ${ }^{72}$

But liquid in health, why should blood clot in disease, in the same way as it does when shed? 'Low temperature' was one theory, superseded by 'slow motion', disproved in turn by John Hunter. With Berzelius' discovery of catalytic action the chemical line of interpretation was opened. Johannes Müller postulated a soluble precursor of fibrin, called 'fibrinogen' by his one-time student Virchow. After Buchanan had demonstrated the need for a second substance to bring about coagulation, the foundations for present-day knowledge were laid by Virchow's pupil Alexander Schmidt, and by Hammarsten. ${ }^{73}$

Enzymology, then, and radiation physics-successful versions of iatrochemistry and iatrophysics-came to join the mechanical concepts of blood flow. The basic sciences began to create impatience with those who merely made their observations at the bedside and the anatomy slab. But whether we care to remember them or not, these men, the Greek physicians with their descriptions for the sake of prognosis, the nosologists with their classifications, the system builders with their preconceived causes, and the plodding morphologists, have supplied us with an indispensable and indestructible framework of reference whenever we think about strokes.

${ }^{70}$ Paul Broca, 'Sur les températures morbides locales', Bull. Acad. Méd., 1879, 2e sér., 8, 1331-46.

Josiah Stickney Lombard, 'Experimental researches on the temperature of the head', Proc. $R$. Soc. Lond. 1878, 27B, 166-77.

Moritz Schiff, 'Recherches sur l'échauffement des nerfs et des centres nerveux, etc.', Arch. physiol. norm. path., 1870, 3, 5-25, 198-214, 323-33; 1870, 451-462.

For a modern, independent, and unconscious revival of this idea, as related to stroke, which had been Broca's main concern, see A. Heyman, 'Thermography', in C. H. Millikan, R. G. Siekert, and Whisnant, Cerebral Vascular Disease (5th Conference), New York, Grune \& Stratton, 1966, p. 112-23.

${ }^{11}$ H. Fischgold, 'D'Angelo Mosso à Hans Berger, Comment est née l'électroencéphalographie', in L. Belloni, Essays on the History of Italian Neurology, Milan University Press, for Instituto di Storia della Medicina, 6, 1963, pp. 237-54.

72 S. S. Kety, 'The cerebral circulation', in Fischman and Richards, Circulation of the Blood-Men and Ideas, London and New York, Oxford University Press, 1964, pp. 703-42.

${ }_{73}$ Paul Morawitz, The Chemistry of Blood Coagulation (1905), trans. R. C. Hartmann and P. F. Guenther, Springfield, Ill., Thomas, 1958. 